\title{
PENENTUAN RUMUS PEMBUSUKAN IKAN \\ MENGGUNKAN METODE CURVE FITTING DENGAN PENDEKATAN PENGOLAHAN CITRA TERHADAP CITRA DIGITAL INSANG IKAN
}

\author{
Luther Latumakulita \\ Program Studi Matematika, FMIPA, Universitas Sam Ratulangi \\ J1. Kampus UNSRAT Bahu, Manado, 95115 \\ Telp : (0431) 852959, Fax : (0431) 823705 \\ E-mail: lutherlatu@gmail.com
}

\begin{abstract}
Abstrak
Pengolahan citra digital (digital image processing) merupakan teknik-teknik pengolahan citra yang saat ini banyak dimanfaatkan dalam berbagai bidang. Dalam penelitian ini, Digital Image Processing digunakan untuk meneliti proses pembusukan ikan mujair (Oreochromis Mossambicus).

Citra yang diolah sebanyak 11 citra insang yang diambil dari seekor ikan mujair. Periode Pengambilan masing-masing citra dilakukan dalam setiap 1 jam terhitung mulai ikan tersebut mati hingga membusuk. Langkah selanjutnya adalah menghitung nilai warna merah pada setiap citra insang menggunakan perbandingan perhitungan RGB kemudian dilakukan penentuan rumus pembusukan dengan menggunakan metode curve fitting. Langkah terakhir adalah menghitung nilai rata-rata error dengan menggunkakan metode linier, kuadratik dan kubik sehingga diperoleh error terkecil.

Hasil penelitian menunjukan bahwa terdapat perbedaan warna merah pada citra insang dan cenderung berkurang seiring bertambahnya waktu semenjak ikan tersebut mati hingga membusuk, sehingga disimpulkan bahwa kandungan warna merah dalam insang ikan banding terbalik dengan bertambahnya waktu menuju pembusukan ikan.
\end{abstract}

Kata Kunci: Pengolahan Citra Digital, Curve Fitting, Citra Insang Ikan, Oreochromis Mossambicu

\section{Pendahuluan}

Penglihatan adalah merupakan indra yang paling peka sehingga sangat berperan penting dalam persepsi manusia terutama terhadap sebuah citra. Suatu citra dapat didefinisikan sebagai fungsi dua dimensi $\mathrm{f}(x, y)$, di mana $x$ dan $y$ adalah koordinat spasial dan amplitudo dari $f$ pada sembarang pasangan koordinat $(x, y)$ disebut intensity (intensitas) atau gray level (level keabuan) dari citra pada titik tersebut [1]. Pengolahan citra digital dibangun berdasarkan atas fondasi formulasi matematika dan probabilistik. Citra ditinjau dari sudut pandang matematis merupakan fungsi yang kontinu dari intensitas cahaya pada bidang dua dimensi. Sedangkan, citra digital adalah citra yang ditangkap kamera dan telah mengalami proses kuantitasi dalam bentuk diskrit (digitalisasi).

Indonesia mempunyai perairan yang begitu luas terutama untuk berkembangnya ikan-ikan yang akan menjadi sumber protein hewani dengan jumlah berlimpah. Ikan, merupakan pangan yang mudah rusak (perishable). Ikan yang dibiarkan mati setelah penangkapan, akan cepat mengalami pembusukan bahkan lebih cepat daripada bahan pangan yang lain. Pembusukan tersebut dapat terjadi akibat enzimatis, kimia dan kegiatan mikroba. Seperempat bahan pangan didunia dan $30 \%$ produk perikanan rusak akibat pembusukan oleh mikroba (Ghaly et al 2010). Ikan mujair (Oreochromis Mossambicus) merupakan ikan yang hidup diperairan air tawar yang sejak dahulu telah dikonsumsi manusia dan merupakan sumber protein, vitamin, dan mineral yang diperlukan oleh tubuh. Insang merupakan organ respirasi yang utama dan vital pada ikan. Epitel insang ikan merupakan bagian utama untuk pertukaran gas, keseimbangan asam basa, regulasi ion, dan ekskresi nitrogen [2]. Fakta sehari-hari menunjukan bahwa salah satu indikator dalam memprediksi kesegaran ikan adalah dengan mengamati warna merah pada insang ikan. Bertolak dari fakta tersebut, dalam penelitian ini akan dilakukkan pengolahan citra digital insang ikan mujair untuk mengetahui rumusan yang menunjukan proses pembusukan ikan. 


\section{Pemrosesan Warna}

Warna merupakan spektrum tertentu dalam suatu cahaya sempuran dimana identitasnya ditentukan oleh panjang gelombang cahaya tersebut. Masingmasing warna mampu memberikan kesan dan identitas tertentu sesuai dengan pengamatan. Penelitian menunjukkan bahwa kombinasi warna yang memberikan rentang warna yang paling lebar adalah RGB (Red,Green, Blue), ketiga warna yang merupakan warna pokok (primaries).

Suatu warna tertentu akan didefinisikan sebagai penggabungan tiga warna dasar dengan intensitas tertentu pada setiap warna dasarnya. Perkiraan warna red, green, blue dibutuhkan untuk membentuk sembarang warna tertentu yang disebut dengan nilai tristimulus dan dinyatakan dengan X, Y dan Z. Sebuah warna ditentukan oleh trichromatic coefficients, didefinisikan sebagai:

$$
\begin{aligned}
& X=\frac{X}{X+Y+Z} \\
& Y=\frac{X}{X+Y+Z} \\
& Z=\frac{X}{X+Y+Z} \\
& \text { Dimana: } \\
& \mathrm{X}=\text { Red } \\
& \mathrm{Y}=\text { Green } \\
& \mathrm{Z}=\text { Blue }
\end{aligned}
$$

\section{Pencocokan Kurva}

Suatu data yang diperoleh dilapangan umumnya berbentuk diskrit dan disajikan dalam bentuk tabel. Data tersebut tentunya diperoleh dari hasil riset di lapangan atau hasil percobaan di laboratorium. Masalah yang sering dijumpai terhadap suatu data adalah menentukan suatu nilai di antara titik-titik dari data tersebut tanpa melakukan perhitungan lagi. Salah satu solusinya adalah dengan mencari fungsi yang mencocokkan titik-titik dari data tersebut, pendekatan ini disebut pencocokan kurva (curve fitting) dan fungsi yang diperoleh adalah fungsi hampiran dimana hasilnya tidak setepat nilai eksaknya. Dalam kasus ini metode-metode yang digunakan sebagai berikut:

- $\quad$ Metode Linear

Interpolasi Linear merupakan metode pencocokan kurva yang dibuat sedemikian sehingga selisih antara titik data dengan titik hampirannya di kurva sekecil mungkin, dimana interpolasi linear melalui dua titik $\left(x_{0}, y_{0}\right),\left(x_{1}, y_{1}\right)$ dengan persamaan garis lurus $y=A x+B$, merupakan penyelesaian untuk system linear yang dikenal dengan persamaan normal.

- $\quad$ Metode Kuadratik

Interpolasi kuadratik melalui tiga titik $\left(x_{0}, y_{0}\right),\left(x_{1}, y_{1}\right)$, dan $\left(x_{2}, y_{2}\right)$ yang merupakan persamaan parabola $y=a x_{0}^{2}$ $+\mathrm{b} x_{0}+c$ dimana $a, b$ dan $\mathrm{c}$ adalah konstanta.

- Metode Kubik

Interpolasi kubik melalui empat titik $\left(x_{0} y_{0}\right),\left(x_{1}, y_{1}\right), \quad\left(x_{2}, y_{2}\right)$, dan $\left(x_{3}, y_{3}\right)$, adalah polynomial derajat tiga (polinom interpolasi) $y=a x^{3}+$ $\mathrm{b} x^{2}+c x+d$ dimana $\mathrm{a}, \mathrm{b}, \mathrm{c}$ dan $\mathrm{d}$ adalah konstanta.

\section{Metodologi Pemecahan Masalah}

Dalam membangun penelitian ini beberapa metode yang dilakukan diantaranya

1. Studi Literatur.

Mempelajari konsep dan teori yang berkaitan dengan pengolahan citra digital, pemrosesan warna citra dan anatomi insang ikan mujair dan konsepkonsep lain yang terkait.

2. Teknik Memperolah Data Citra Insang Ikan Mujair.

Data citra insang ikan mujair diperoleh dengan cara melakukan pemotretan menggunakan kamera digital terhadap insang ikan mujair yang dilakukan dalam periode waktu tiap 1 jam selama 11 jam. Teknik pemotretan dilakukan sedemikian sehingga dapat meminimalkan perbedaan efek pencahayaan dalam setiap kali pemotretan

Tahapan Penelitian

1. Pengambilan citra insang ikan selama 11 jam dengan rentang waktu pengambilan gambar dalam selang 1 jam terhitung mulai saat ikan mati hingga membusuk.

2. Menghitung warna merah dalam setiap citra insang ikan.

3. Melakukan penentuan rumus dengan metode fitting curve. 
4. Menghitung nilai error dengan menggunakan metode linier, metode kuadratik dan metode kubik.

5. Membandingkan nilai error dari semua metode pada tahap empat

6. Menarik Kesimpulan penelitian

\section{Pembahasan}

Gambar berikut merupakan contoh gambar insang ikan yang diambil dengan keterangan gambar menunjukan jam pengambilan gambar

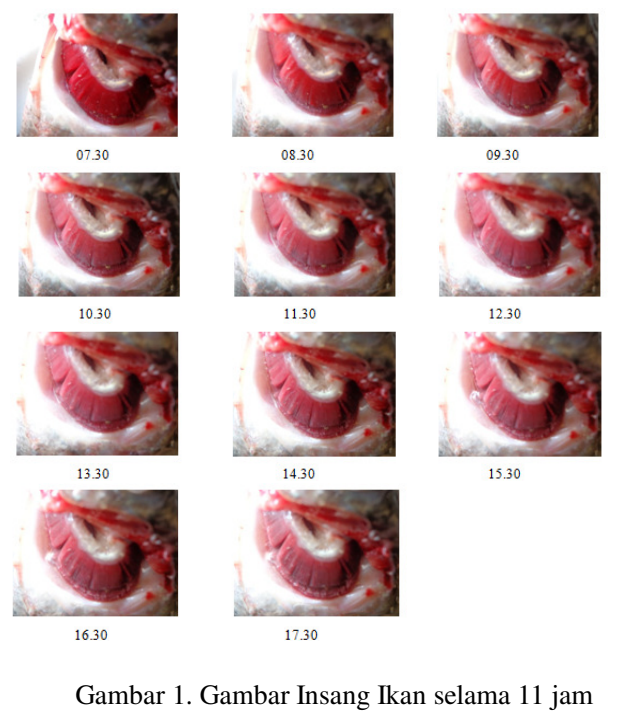

Berdasarkan hasil citra digital yang diperoleh, dilanjutkan dengan penentuan warna merah dengan menggunakan rumus (1) yang hasilnya dapat dilihat pada Tabel 1 berikut:

Tabel 1. Tabel Jumlah Warna Merah Pada Citra Insang

\begin{tabular}{|c|l|c|}
\hline NO. & \multicolumn{1}{|c|}{ JAM KE- } & JUMLAH RED : $X=\frac{x}{x+\gamma+z}$ \\
\hline 1 & Pertama (07.30) & 0,3939 \\
\hline 2 & Kedua (08.30) & 0,3914 \\
\hline 3 & Ketiga (09.30) & 0,3898 \\
\hline 4 & Keempat (10.30) & 0,3891 \\
\hline 5 & Kelima (11.30) & 0,3882 \\
\hline 6 & Keenam (12.30) & 0,3878 \\
\hline 7 & Ketujuh (13.30) & 0,3874 \\
\hline 8 & Kedelapan (14.30) & 0,3869 \\
\hline 9 & Kesembilan (15.30) & 0,3846 \\
\hline 10 & Kesepuluh (16.30) & 0,3830 \\
\hline 11 & Kesebelas (17.30) & 0,3810 \\
\hline
\end{tabular}

Dari data jumlah warna merah yang diperoleh, langkah selanjutnya adalah dengan menentukan suatu model rumus menggunakkan metode linear, kuadratik, dan kubik yang terdapat pada teknik curve fittng dan hasilnya dapat dilihat pada Gambar 2 berikut ini:

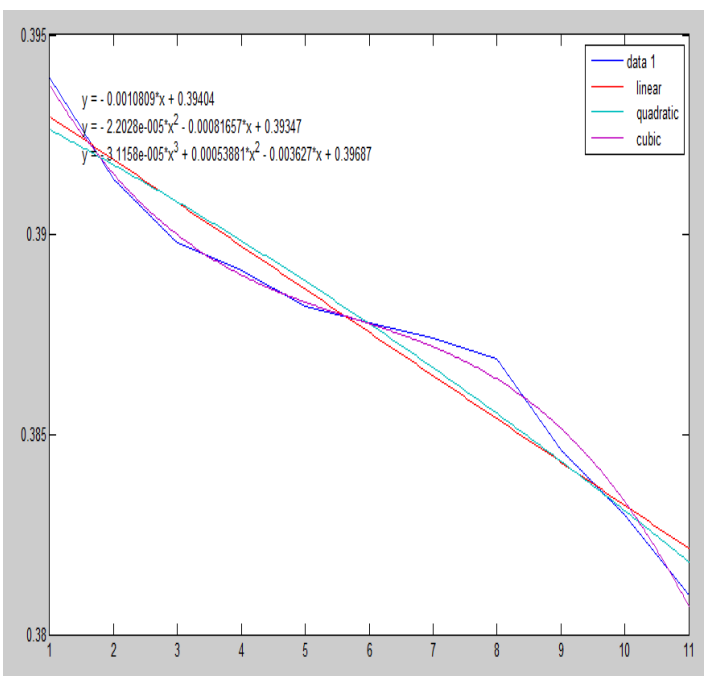

Gambar 2 Kurva Jumlah Warna Merah

Variabel $x$ mewakili waktu dalam satuan jam dan variable y mewakili jumlah warna merah pada insang ikan. Langkah selanjutnya adalah mencari error rata-rata yang dapat dilihat pada table 2 berikut ini:

Tabel 2: Tabel Perhitungan Rata-Rata Error

\begin{tabular}{|c|c|c|c|c|c|c|c|}
\hline$x$ & $y$ & Linier & Kuadratik & Kubik & Eror Linier & Eror Kuadratik & Eror Kubik \\
\hline 1 & 0.3939 & 0.3889 & 0.389158 & 0,396909 & $50,00 \%$ & $47,42 \%$ & $30,09 \%$ \\
\hline 2 & 0.3914 & 0.3878 & 0.388272 & 0,394712 & $36.00 \%$ & $31.28 \%$ & $33.12 \%$ \\
\hline 3 & 0.3898 & 0.3867 & 0.387342 & 0.393223 & $31.00 \%$ & $24.58 \%$ & $34.23 \%$ \\
\hline 4 & 0,3891 & 0.3856 & 0.386368 & 0,392256 & $35.00 \%$ & $27,32 \%$ & $31.56 \%$ \\
\hline 5 & 0.3882 & 0.3845 & 0.38535 & 0.391625 & $37,00 \%$ & $28.50 \%$ & $34.25 \%$ \\
\hline 6 & 0.3878 & 0.3834 & 0.384288 & 0,391144 & $4,00 \%$ & $35.12 \%$ & $33.44 \%$ \\
\hline 7 & 0.3874 & 0,3823 & 0.383182 & 0,390627 & $51,00 \%$ & $42.18 \%$ & $32.27 \%$ \\
\hline 8 & 0,3869 & 0.3812 & 0.382032 & 0,389888 & $57.00 \%$ & $48.68 \%$ & $29.88 \%$ \\
\hline 9 & 0.3846 & 0,3801 & 0.380838 & 0,388741 & $45.00 \%$ & $37,62 \%$ & $41,41 \%$ \\
\hline 10 & 0.383 & 0,379 & 0.3796 & 0.387 & $40,00 \%$ & $34,00 \%$ & $40,00 \%$ \\
\hline 11 & 0.381 & 0.3779 & 0.378318 & 0.384779 & $31.00 \%$ & $26.82 \%$ & $34.79 \%$ \\
\hline \multicolumn{5}{|c|}{ Rata-rata Eror } & $41.55 \%$ & $34.87 \%$ & $34,09 \%$ \\
\hline
\end{tabular}

Dengan demikian diperoleh rumus dan error dari masing-masing metode yang digunakan dan metode kubik menunjukkan hasil error yang paling kecil. 


\section{Kesimpulan}

Kesimpulan dari penelitian ini adalah:

1. Hasil penelitian menunjukan bahwa terdapat perbedaan warna merah pada citra insang dan cenderung berkurang seiring bertambahnya waktu semenjak ikan tersebut mati hingga membusuk, sehingga disimpulkan bahwa kandungan warna merah dalam insang ikan banding terbalik dengan bertambahnya waktu menuju pembusukan ikan.

2. Dengan menggunakan metode curve fitting dapat ditentukan rumus pembusukan ikan mujair. Nilai rata-rata error terkecil diperoleh dengan menggunakan metode kubik.

\section{Referensi}

[1] Eko Prasetyo, Pengolahan Citra Digital dan Aplikasinya Menggunakan MATLAB, Penerbit Andi, Yogyakarta:2011

[2] Ivan Maulana Ersa, Gambaran Hispatologi Insang, Usus dan Otot pada Ikan Mujair (Oreochromis mossambicus) di Daerah CIAMPEA BOGOR, FAKULTAS KEDOKTERAN HEWAN INSTITUT PERTANIAN BOGOR BOGOR, 2008. 